
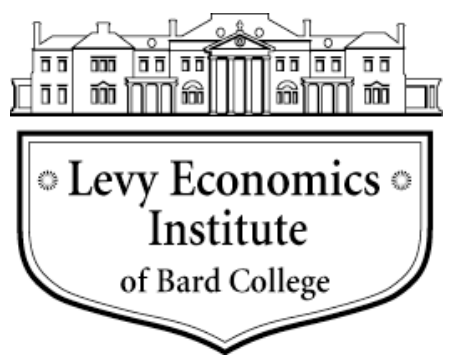

Working Paper No. 832

\title{
The Rise of Money and Class Society: The Contributions of John F. Henry \\ by
}

\author{
Alla Semenova* \\ State University of New York, Potsdam \\ L. Randall Wray ${ }^{\dagger}$ \\ Levy Economics Institute of Bard College
}

February 2015

*alla.semenova@gmail.com

†WrayR@umkc.edu

The Levy Economics Institute Working Paper Collection presents research in progress by Levy Institute scholars and conference participants. The purpose of the series is to disseminate ideas to and elicit comments from academics and professionals.

Levy Economics Institute of Bard College, founded in 1986, is a nonprofit, nonpartisan, independently funded research organization devoted to public service. Through scholarship and economic research it generates viable, effective public policy responses to important economic problems that profoundly affect the quality of life in the United States and abroad.

Levy Economics Institute P.O. Box 5000

Annandale-on-Hudson, NY 12504-5000

http://www.levyinstitute.org 


\begin{abstract}
This paper explores the rise of money and class society in ancient Greece, drawing historical and theoretical parallels to the case of ancient Egypt. In doing so, the paper examines the historical applicability of the chartalist and metallist theories of money. It will be shown that the origins and the evolution of money were closely intertwined with the rise and consolidation of class society and inequality. Money, class society, and inequality came into being simultaneously, so it seems, mutually reinforcing the development of one another. Rather than a medium of exchange in commerce, money emerged as an "egalitarian token" at the time when the substance of social relations was undergoing a fundamental transformation from egalitarian to class societies. In this context, money served to preserve the façade of social and economic harmony and equality, while inequality was growing and solidifying. Rather than "invented" by private traders, money was first issued by ancient Greek states and proto-states as they aimed to establish and consolidate their political and economic power. Rather than a medium of exchange in commerce, money first served as a "means of recompense" administered by the Greek citystates as they strived to implement the civic conception of social justice. While the origins of money are to be found in the origins of inequality, a well-functioning democratic society has the power to subvert the inequality-inducing characteristic of money via the use of money for public purpose, following the principles of Modern Money Theory (MMT). When used according to the principles of MMT, the inequality-inducing characteristic of money could be undermined, while the current trends in rising income and wealth disparities could be contained and reversed.
\end{abstract}

Keywords: Nature of Money; Chartalism; Metallism; Origins of Money; Origins of Coinage; Inequality; Class; Ideology; Religious Ideology; State Formation; State Theory of Money; Modern Money Theory

JEL Classifications: B5, B25, B41, E11, E12, E42, E52, E62, E63, H6, N1, N2, P1, P4, P5, Z1 


\section{INTRODUCTION}

The devastating trends in social and economic inequality in developed industrialized nations have been the subject of a growing body of literature - economic and non-economic alike (see Piketty 2014; Taibbi 2014; Stiglitz 2013; Reich 2013; Wilkinson and Pickett 2009). While the experience of the Great Recession and the ensuing discussion of grotesque inequality have made it obvious that the present trends in rising income and wealth disparities are unsustainable and must be contained and reversed, few scholars have examined the nature of socioeconomic inequality itself. Was the rise of inequality part of a natural and, thus, inevitable progression of societies? Is inequality a natural and, hence, unavoidable trait of socioeconomic organization?

For those who thought that inequality was natural and inescapable, John Henry (2004) presents a convincing account of the not-so-natural rise of socioeconomic disparities and classes in ancient Egypt. In fact, Henry's contribution clearly demonstrates that the rise of inequality in ancient Egypt was more akin to an accident of history (though a gradually occurring one), rather than history's natural progression. Having emerged accidentally, inequality came to be cemented, perpetuated, and widely accepted as a "normal" and, thus, ever-present characteristic of societies.

The role of ideology in rationalizing and maintaining the status quo in unequal societies is an issue Henry tackles with no less equal passion than the rise of inequality itself (see Henry 1990). Henry examines the rise of such ideology in western societies, including John Locke's elaborate theoretical justification of unequal distribution of wealth (see Bell et al. 2004). In his case study of ancient Egypt, Henry (2004) shows how religious ideology played a crucial part in justifying the newly emerging hierarchical social structures.

The final and critical point Henry makes is that the rise of class society and inequality took place alongside the emergence of money, whereby money played a key role in establishing, maintaining and exacerbating inequality and class division in societies (see Henry 2004). To put it simply, as soon as one witnesses the emergence of money, one observes the rise of class society and socioeconomic inequalities. Money, class society, and inequality came into being simultaneously, so it seems, mutually reinforcing the development of one another.

We believe that Henry's account of the rise of money, social classes, and inequality in ancient Egypt has important implications for today's discourse on growing income and wealth disparities in developed industrialized economies. First and foremost, there is nothing natural 
about the existence of socioeconomic inequality. Secondly, the current trends in income and wealth disparities could and should be reversed. While we do not argue that perfect equality is possible or even desirable in developed industrialized societies (for reasons that are beyond the scope of this chapter), we do contend that the current state of income inequality could and should be remedied via the use of modern money for public purpose following the principles of Modern Money Theory (MMT) (see Wray 2012a, 2014a, 2014b, 2014c, 2014d).

The above propositions inevitably lead us to the discussion of money, its origins and nature, and the underlying link between money, authorities and inequality. While it is true that money, inequality and class society developed hand in hand, mutually reinforcing the emergence and consolidation of one another, the inequality-inducing characteristic of money could be greatly (though far from entirely) subverted and undermined, if money were to be used according to the principles of MMT. If used according to the principles of MMT, money could serve the greater public purpose of improving the living standards of the majority of the population of this planet. Thus, rather than doing away with the institution of money, MMT proposes to finally make this institution serve the greater public good.

In what follows, we will begin with a discussion of the nature of money, presenting two contending perspectives on the subject — chartalism and metallism — devoting more attention to the former. In doing so, we will summarize the contributions of a handful of major thinkers whose work was instrumental in the development of the chartalist approach. We will then present two historical case studies of money's origins - in ancient Greece and ancient Egyptdemonstrating the reciprocal relationship between the rise of money, class society, and inequality. It will be shown that religious and other ideology played a crucial role in the rise of money, classes, and inequality in both regions examined. This chapter concludes with a brief discussion of the use of modern money for public purpose, such as the reversal of the current trends in income and wealth disparities, following the principles of MMT.

\section{CHARTALISM AND METALLISM: AN OVERVIEW}

Charles Goodhart (1998) was among the first scholars to introduce a distinction between the orthodox "metallist" and the heterodox "chartalist" approaches to the nature and origins of money. Following Geoffrey Ingham (1996, 2000, 2004a), John Henry (2004) made a closely 
related distinction between "those theories that see money as a technical development [Metallism], and those proposing that money is a social relationship [Chartalism]" (78).

In the metallist approach, money comes into being when a commodity serves as a universal medium of exchange (such as gold or silver metal) in private sector markets. Money is a spontaneous private sector development aimed at overcoming the economic inefficiencies of barter. Although the primary focus of metallism is the medium of exchange function of money, metallist scholars do not exclude other money functions, nor do they advocate a return to a gold standard. However, the metallist vision leads directly to specific policy prescriptions, including the view that money's value is linked to its scarcity (Wray 2014a). ${ }^{1}$

Alongside the misconception that money is a thing, metallism promotes the notion of "an underlying equality among the participants in the exchange relationship" (Henry 2004, 78). "As exchange must be voluntary in order for all parties to benefit, no coercive arrangements can exist that would negate freedom of choice" (78). Henry thus reminds us that the metallist account of money's origins necessarily excludes social and economic inequalities and hierarchies, as money facilitates trade among equal, classless, and free participants in the voluntary exchange.

While metallism views money's origins as a spontaneous private sector development, chartalism highlights the important role played by the "authorities" in the origins and evolution of money. In the chartalist approach, the "state" (or any other public authority able to impose an obligation) imposes a liability in the form of a generalized, social or legal unit of account-a money - used for measuring (or denominating) the obligation. Money is introduced by the state as a unit of account in which debts and other obligations to the state are denominated and have to be repaid. It is from this power to extinguish debts and other obligations to the state that money acquires its value. Money's intrinsic value is therefore irrelevant, for the state could theoretically choose and introduce any unit of account as money (Wray 1998, 2012c, 2014a).

The chartalist context of money's origins therefore reveals unequal power relations and social hierarchies. If money "represents a relation between those who claim [the] obligations and those who must service those claims" (Henry 2004, 78), the existence of money necessarily presupposes a social divide between those who are able to impose obligations and debts and those who must service them. As Henry puts it, the chartalist "theories necessarily connote (or at least imply) some underlying inequality, as those who claim obligations must be in a superior 
position to those who are obligated to the former. Otherwise, there would be no social reason to fulfill said obligations or any mechanism to enforce payment" (78-79).

In what follows, we will discuss the chartalist perspective in more detail by surveying the contributions of Knapp, Innes, Grierson, and Ingham - the scholars whose work was important in building a modern version of chartalism, an approach now called Modern Money Theory (MMT).

\section{THE CHARTALIST TRADITION: THE CONTRIBUTIONS OF KNAPP, INNES, GRIERSON, AND INGHAM}

\section{Knapp and the State Theory of Money}

Georg Friedrich Knapp developed the "state theory of money" view, which is directly opposed to the metallist approach, according to which the value of money derives from the value of the metal standard adopted. More generally, Knapp is critical of the metallists' attempts to "deduce" the monetary system "without the idea of a State." This, he believes to be "absurd," for "the money of a state" is that which is "accepted at the public pay offices" (Knapp 1924, viii; see also Goodhart 1989, 1998; Wray 1998, 2014a). The political science aspect of Knapp's approach is the inseparability of the institutions of money and the state, for money is always “associated with the State which introduces it" (Knapp 1924, 40).

Chartalism, however, should not be misidentified with the proposition that legal tender laws determine that which must be accepted as means of payment. The ultimate test of moneyness is "that the money is accepted in payments made to the State's offices" (Knapp 1924, 95). The state first decides what it will use or accept as money in its own transactions, and this must then be accepted as means of settlement of private debts. As Abba Lerner (1947) noted, "a simple declaration that such and such is money will not do" (313). Rather, "the trick is done" when "the state is willing to accept the proposed money in payment of taxes and other obligations to itself" (313). Or, as Keynes famously said, the state "claimed the right not only to enforce the dictionary but also to write the dictionary" (Keynes 1930, 5). The material used to manufacture the monetary unit is wholly irrelevant - it can be gold, silver or common metal; it can be paper and today, it can be electronic entries on tape or hard-drive (Wray 2014a). Money is simply a "ticket," a "token," a chartal ${ }^{2}$ means of payment that the state issues and accepts in payment of taxes, fines and fees. 


\section{Innes and the Credit Money Approach}

A. Mitchell Innes $(1913,1914,1932)$ advanced the state theory of money view along with the credit money approach. A sale, according to Innes, is "the exchange of a commodity for a credit" (Innes 1913, 391). Rather than a medium of exchange, money is an acknowledgement of one's debt, or money is credit, if viewed from the perspective of the creditor. Innes notes that the verb "to pay" has the root meaning "to appease," "pacify" or "satisfy" (392), and maintains that the "really important" characteristic of money is "the right that it confers on the holder to liberate himself from debt by its means" (393). The "primitive law of commerce," according to Innes, is the "the creation of credits and debts, and their extinction by being cancelled against one another" (393). "The presence of a law of debt," "the sanctity of an obligation," argues Innes, is the foundation of all societies of which we have historical records (391).

Observing that some of the earliest commercial documents were found in Babylonian temples, Innes (1913) underscores the relationship between money, debt, public authorities, and religion, attributing "the origin of all fairs" to religious festivals, the primary purpose of which was the settlement of debts (397).

There is little doubt to my mind that the religious festival and the settlement of debts were the origin of all fairs and that the commerce which was there carried on was a later development. If this is true, the connection between religion and the payment of debts is an additional indication if any were needed, of the extreme antiquity of credit (ibid.).

Finally, Innes extends his analysis to incorporate the state. When the government spends, it becomes a debtor as it issues state money or acknowledgements of the state's indebtedness (Innes 1914, 154). However, unlike the private sector debt, the government's money is a special kind of credit, "redeemed by taxation" (168). Whether the state's IOU is printed on paper or on a gold coin is irrelevant, for the state is indebted just the same. Historically, the monetary records (of those debts) included clay tablets, hazelwood sticks, and base metal coins, as well as paper certificates (Innes 1913).

Lastly, Innes's (1932) work on criminal justice and money shares important links to the work of Philip Grierson $(1975,1977)$. Grierson traced the origins of money to the ancient tradition of wergeld. 


\section{Grierson and the Role of Wergeld in the Origins on Money}

A renowned numismatist, Philip Grierson $(1975,1977)$ famously proclaimed that "money lies behind coinage" $(1977,12)$, thereby rejecting the orthodox belief that the origins of money could be reduced to the emergence of coinage or the use of metal as a medium of exchange. For Grierson, coinage is merely a "specific" case within the general phenomenon of money, the history of which is "much more complex" compared to that of coinage which is "relatively simple" $(1977,12)$. The history of money, according to Grierson, is first and foremost a history of the emergence of an abstract unit of account. Accounting for the marginality of trade (both foreign and domestic) in archaic and ancient societies, Grierson $(1975,1977)$ rules out the belief that a unit of account developed within a market context. Turning to linguistic evidence, Grierson (1977) observes that the Greek word for "price"- time - meant "compensation," "satisfaction" and "penalty" (27). Through a detailed investigation of historical records, Grierson $(1975,1977)$ further discovered a range of evidence for the emergence of measurement systems and units of account within the ancient tradition of wergeld.

Derived from wair meaning "man" and gildan meaning "to pay" or "to render" (Grierson 1977, 22), the term wergeld refers to the ancient tradition of paying in-kind compensations for personal injuries to, or murders of, kin members. By compensating the family of an injured or murdered person, retaliation by force, blood feud, and other "inconvenient social consequences" could be avoided (19). wergeld fines were assessed and levied by public assemblies, and each transgression was associated with a particular fine. Payments, on the other hand, were made "directly to the victims or their families [and] not to public institutions" (Hudson 2004, 99). A designated rememberer was responsible for passing the list of fines to the next generation. Initially, each fine was levied in terms of a specific good that was both useful to the victim's family and more-or-less easily obtainable by the transgressor (Wray 2014a).

While wergeld required social consensus on the form of compensation to the victim, there was no need for a standardized unit of account, for each injury was associated with a specific fine paid by the transgressor (see Wray 1998, 2004). Gradually, however, specific wergeld debts owed to victims and their families were transformed into general monetary debts owed to the authorities such as fees, fines, tithes, tribute, and taxes (see Grierson 1975, 1977; Wray 1998, 2004, 2014a; Wray and Bell 2004). Therefore, while the wergeld tradition did not directly generate a standardized unit of account, wergeld gave rise to the notion of debt and a 
unit of measurement. As Grierson puts it, the wergeld tradition provided "the prerequisites for the establishment of a monetary system" (Grierson 1977, 20). Yet, it is only when wergeld fines were transformed into standardized payments made to authorities that money emerged as a standardized unit of account. This transformation could not take place "in an egalitarian, democratic, tribal society, but had to await the rise of some sort of ruling class" (Wray 2004, 227).

\section{Ingham and Money as a "Social Relation"}

By bringing in a historical perspective along with the sociology of money, Geoffrey Ingham has made important contributions toward the development of the chartalist approach. Siding with Grierson, Ingham underscores that "coin is not the origin of money" (2004a, 97), for historical evidence points to the origins of money as a unit of account for the assessment of social and political obligations. Such debts could initially take the form of wergeld payments, gradually evolving into tax and rent obligations due to the authorities. In Ingham's view, "a stable and uniform measure of value can only be produced by an authority outside the sphere of exchange - usually, but not necessarily a state" (Ingham 2013, 132). Obviously, the ability to establish a standardized unit of account is "inherently a source of power" (Ingham 2004b, 20).

The above discussion leads us to one of Ingham's most important contributions, specifically, the view of money as "a system of social relations based on power relations and social norms" (Ingham 2000, 19). Rather than a thing, money is "a social relation of credit and debt" (Ingham 2004a, 25; see also Ingham 1996), which is by its nature an unequal social relation. Henry (2004) elucidates this point well: "For every debtor there must be a creditor, and such a relationship is one of inequality with creditors having economic power over debtors" (84). Obviously, there could be no debt in egalitarian societies organized around the practice of hospitality (see Bell and Henry 2001). ${ }^{3}$ 


\section{THE RISE OF MONEY AND CLASS SOCIETY: THE CASE OF ANCIENT GREECE}

\section{The Standardization of the Ox-unit of Value and Account}

A pre-market, religious context of money's origins in ancient Lydia and Greece was first

explored by Bernhard Laum (1924). ${ }^{4}$ Laum's primary focus is the origins of the ox-unit of value and account, the conventional unit of measurement in ancient Lydian and Greek societies.

Because the institution of trade, both foreign and domestic, played a marginal role in ancient Greek and Lydian societies, it would be unlikely that the ox-unit developed in a market context (Laum 1924; for the marginality of trade see also Kurke 1999; von Reden 2003; Seaford 2004; Semenova 2011a, 2011b; Peacock 2013). Rather than market exchange, ancient Greek and Lydian economies exhibited "the centrality of reciprocity and redistribution as principles of allocation" (Seaford 2004, 27).

For the purposes of the present discussion, the most important redistributive activity was that of a highly ritualized communal sacrificial meal. Conducted in honor of a commonlyworshiped divinity, the tradition consisted of a public killing, roasting, and eating of sacrificial animals. The objective of the ritual was to establish solidarity and social cohesion among the members of the community. Perhaps the most prominent feature of the communal sacrificial model was its egalitarian emphasis, manifest in "just" and "equal" distribution of roasted bull's meat among the ritual participants (Seaford 2004). In six lengthy descriptions of sacrifice, Homer stressed the egalitarian aspect of the ritual via a formulaic sentence: " "they feasted, nor was anybody's hunger denied the equal feast" " $(40){ }^{5}$

While the ritual employed the principles of collective participation (koinonia) and "equal distribution to all" (Seaford 2004, 41), one's equal share corresponded to one's social status: "to the order of social rank there corresponded an order of rank in the apportionment of the roasted flesh" (Desmonde 1962, 116). The just shares allocated to ritual participants differed not only in quantity, but in quality as well. The more honored parts of the sacrificial animal, such as the limbs, were customarily allotted to religious officials.

In this manner, the sacrificial repast reflected the principle of proportionate rather than absolute equality (see Semenova 2011a, 2011b). Proportionate equality "gives to the greater more and to the inferior less and in proportion to the nature of each" (Plato Laws 757, in Spengler 1980, 88-89). Yet, the principle of proportionate equality did not repudiate the 
egalitarian aspect of the communal feast: equality did prevail - in proportion to the social standing of the communicant (see Spengler 1980; Minar 1942). Purporting to allocate just and equal shares to the members of the not-so-equal community, the all-inclusive rituals of communal sacrificial meals aimed to create an appearance of harmonious and consensual social relations, thus concealing the underlying reality of social hierarchies and economic inequalities. As Henry (2004) would put it, "the façade of equality had to be maintained while inequality was growing and solidifying" $(87) .^{6}$

To service the ritual, sacrificial offerings were made, mostly in oxen, whereby religious officials stipulated the precise quality, type and quantity of cattle to be contributed, thereby establishing the first standardized unit of account guaranteed by the authorities (Laum 1924; Desmonde 1962; Seaford 2004; Semenova 2011a, 2011b; Peacock 2013).

Sacrificial cattle ... were subject to qualitative standardization, according to type, age, sex, colour, being unblemished, not having been used as work animals ..... One did not, that is, sacrifice just any animal to a deity but rather a carefully selected one which met certain standards (Peacock 2013, 89, original emphasis).

To conclude, the redistributive economies of ancient Greek and Lydian societies were shaped by religion and its normative character, not by the market. Sacrifices to deities represented the presence of a social obligation: mortals were not free to refuse sacrificial interactions with deities (Peacock 2011). This administratively imposed debt relationship between humans and deities gave rise to a standardized unit of account, a unit which did not disappear even after coinage emerged as a creature of a democratic city-state (see Semenova 2011a, 2011b).

Lastly, the redistributive model of communal sacrificial meals was later embraced by the emerging authority of the civic polis as the latter struggled to establish its authority against the powers of the old aristocratic elites. It was within the context of political confrontation between the old aristocracy and the emerging polis that Greek coinage came into being (see Kurke 1999; von Reden 2003; Seaford 2004; Semenova 2011b). In its nature, the earliest Greek coinage was quintessentially chartal.

\section{The Origins of Chartal Greek Coinage}

As is well known, the earliest Greek word for coinage is nomisma. Etymologically, this term is related to nemô meaning "to distribute"; nemesis meaning "distribution of what is due"; and 
nomos meaning "anything allotted or assigned," generally by convention or custom (von Reden 2003, 177; see also Seaford 2004; Kurke 1999). Initially, then, nomisma was associated with distributive order, implying that something was "given out," "distributed" or "measured out" (von Reden 2003, 177). One may conclude that coins became the tokens of "just distribution" of that which was due by convention (177).

The administration of distributive justice is, therefore, key to understanding the origins and functions of early Greek money and coinage. A crisis of redistributive justice can already be observed in Homeric societies, as manifest by excessive appropriation of durable wealth within the community of nobles:

At any rate Homer reveals a world which seems to make sense when viewed as a society in which reciprocity (gift exchange) and hierarchical redistribution were dominant. Certain types of goods circulated in closely defined contexts. Gifts circulating among those of top rank included finished objects of metal, cattle, and women. Meat and related products (hides and textiles) seem to have been controlled from above and redistributed down the social structure (Howgego 1995, 13-14).

The unequal distribution of wealth prompted a "decline of faith in the reliability of divine justice" (von Reden 2003, 175), thereby creating a new social problem of instituting "a political means of payment controlled by humans so that they would not have to rely on the uncertain rewards of the gods" (220). Such means of payment would eventually be established by the civic authority of the polis in the process of its political confrontation with the old aristocracy, the latter being associated with the now-declining authority of divine justice.

In establishing its own model of distributive justice, the emerging authority of the polis adopted the idealized model of communal egalitarian distribution, but substituted durable metal objects for perishable pieces of meat (Seaford 2004). The idea was that "social justice could be achieved politically by the ritual of distribution of pieces of metal" (von Reden 2003, 177). The emerging authority of the polis, then, attempted to dismantle the aristocratic model of power by distributing metal pieces to those who accepted the political authority of the polis instead. The distribution of metal pieces into the hands of the citizens would subvert the aristocracy's monopoly over the use of (precious) metal in the closed sphere of aristocratic gift-giving (Kurke 1999).

At first, the pieces of metal distributed were the iron spits utilized for the roasting of the sacrificial animals. The production of such spits began on a large scale during the late eighth century $\mathrm{BC}$ (or around $700 \mathrm{BC}$ ) leading to their mass production during the entire seventh 
century BC. The roasting spits continued to circulate, though in smaller quantities, until the first half of the sixth century BC. During this period, the roasting spits (which were destined for communal distribution) came to be standardized in size, reflecting the old sacrificial tradition of "equal portions to all" (Seaford 2004, 106). Gradually then, the distribution of roasting spits came to be replaced by the allotment of coinage, which likewise came to be standardized. It is no wonder, then, that obolos, a sixth century BC silver Greek coin, derived its name from obelos meaning an iron spit. Another sixth century BC Greek coin of a larger denomination, drachma, originally meant a handful of six spits (Seaford 2004).

Obviously, the earliest Greek and Lydian coins did not begin as media of exchange in commerce, but functioned "in the same fashion as the portion of food distributed at the sacred meal" (Desmonde 1962, 125). It comes as no surprise, then, that so many of the earliest Greek and Lydian coins bore an image of a bull or a bull's head on their surface (Gardner 1883; Head 1968). Nor could the value of the earliest coins derive from their metal component: the earliest coins emerged in Lydia and were made of electrum, a natural alloy of gold and silver, the internal composition of which is highly variable by nature. This means that a coin's weight, purity and fineness could not be standardized(Grierson 1977; Innes 1913; see also Kurke 1999). Furthermore, Lydian electrum coinage was issued in large 'denominations' and was, therefore, ill-suited for domestic retail trade. According to Cook (1958), the smallest electrum coin was equivalent to about a third of a sheep, while the most commonly issued electrum coinage had an equivalency of about ten sheep (see also Kraay1964, 1976). Rather than facilitate trade, whether foreign or domestic, the initial purpose of coinage was to "(re)establish social justice within the polis" (von Reden 2003, 177). In contrast to the uncertainty associated with divine justice, coinage could compensate virtue "immediately and precisely" (177), and payment in "stamped tokens" came to be associated with "just recompense" (175). ${ }^{7}$ Possession of coinage came to signify the acceptance of the civic authority of the polis $(175){ }^{8}$

Evidently, the value of the earliest coins could not derive from their metal component: the earliest Lydian coins were made of electrum, a natural alloy of gold and silver, the internal composition of which is highly variable by nature. This means that a coin's weight, purity and fineness could not be standardized (Grierson 1977; Innes 1913; see also Kurke 1999).

We do not know for sure the exact mechanism via which coinage circulated during the early stages of its development. What we do know is that coinage was distributed by the polis to its male citizens. It has also been established that some of the earliest monetary "transactions" 
were carried out among unequal social partners, and included sexual "exchange" between men and women. Whether or not all women receiving monetary payments in exchange for provision of personal services could be regarded as prostitutes remains a subject of a growing debate (see von Redden 2003, 195-197). Yet what seems relevant for the purposes of this discussion is that the use of coinage in payment for goods evolved out of its use in payment for personal services. Seaford (2004) seems to imply this transition when he hints that possession of coinage may have financially liberated some women: "[ $\mathrm{t}]$ he greater ease of exchange and of storing wealth that came with precious metal money may have freed some prostitutes from dependence on the protection provided by specific males" (Seaford 2004, 156).

While we may never find out exactly how coinage entered the sphere of market exchange, we may conclude by emphasizing the chartal nature of early Greek coinage. Introduced by the city-state as a unit of account for expressing the worth of its male citizens, the purpose of coinage was to resolve the crisis of distributive justice. Rather than market exchange, coinage was a product of a complex political evolution, and the development of coinage was closely linked to state formation. As will be discussed below, the final choice of silver as the minting metal for coinage was a political decision and had little to do with the intrinsic properties of the metal.

While the rise of coinage and monetization were closely linked to state formation and power, a "thoroughgoing monetization of economic activity" required a more "aggressive insistence of the state" such as "insistence on payments of monetary taxes" (von Reden 2001, 66; see also Kraay 1964). To achieve that, the state would have to "propagate and implement its own commitment to money" (66) by using coinage as a means of payment in its own transactions (see Peacock 2013). According to Seaford (2004), the centralized use of coinage for both state expenditures and contributions to the state, facilitated the democratic control of the financial system:

... this centralized use of coinage both for expenditure (notably uniform mass payments) and for contributions (liturgies, taxes) must have facilitated - after the fall of the tyranny - the control of the financial system by the democracy, which was thereby able to distance such crucial institutions as the military and the law courts from the influence of personal patronage (99). 


\section{The Social and Ideological Significance of Chartal Greek Coinage}

Similar to the pieces of roasted meat distributed during communal sacrificial rituals, the earliest Greek coinage served as "a token of egalitarian ideology" (Kurke 1999, 14). Given the association of gold with the old aristocracy, and the crisis of redistribution as manifest by unequal distribution of metallic wealth (most importantly, gold and gold artifacts), the polis chose silver as the minting metal, and silver coinage aimed to represent "the community of citizens" who were all equal as they were made of "the same noble substance" (309). ${ }^{9}$ Within the Greek polis, citizen rights were materialized precisely via the possession of coinage. "Insofar as a citizen is like a coin, he is not a slave, a metic, a barbarian, or the victim of a tyrant; nor is he overwealthy or divine" (316). The "silver standard" aimed to provide for nonarbitrary and stable valuations of men: a "proper valuation and use of citizens" (299). But could the polis value all men equally?

As is well documented, despite the widespread presence of egalitarian ideology, the Greek polis was highly hierarchical in its social structure. While male citizens were granted a full set of rights, including the right to own land and real estate, the remainder of the population, "in some cases far more numerous, belonged to lower categories and possessed only limited rights" (Migeotte 2009, 39). While public assemblies of free citizens deliberated on decisions of public concern, women were excluded from such decision-making bodies. ${ }^{10}$ Public decisions and executive responsibilities for the running of the polis remained firmly in the hands of male citizens. At the bottom of the social ladder were the slaves, who made up a large portion of the labor force in the household and public domains, as well as in agriculture. "Slavery and servitude were practical necessities," for the ideal of citizenship embodied liberation from manual labor and the pursuit of politics, prayer, and study instead (42; see also Finley 1981).

While citizen rights could be granted to former slaves for their participation in the war efforts, the new citizens would nevertheless be perceived as "wicked little bronzes" (Kurke 1999, 327). This contrast with pure silver citizens obviously implies the presence of "differential citizen quality" as some citizens were more equal than others (327). Furthermore, because they did not enjoy citizen rights, women could not obtain coinage directly from the polis. As von Reden (2003) underscores, coinage remained "an exclusive symbol of man and his city" (206).

Thus, despite the presence of egalitarian ideology, the Greek city-state was plagued by clearly defined socioeconomic hierarchies. While the ideological purpose of coinage was to 
restore greater equality and solidarity, the reality of coinage was that of inequality and exclusion for all but male citizens.

\section{Was the "State Proper" Necessary for the Origins of Money?}

As documented above, religious authorities in ancient Greece were instrumental in the establishment of a standardized unit of account. Here, it bears noting that ancient Greek religion did not occupy "a separate" sphere of social life. Rather, religious practice and ideology were firmly woven into the social, political and economic fabric of society. For practical matters, the relationship between political and religious authorities was difficult to disentangle (Seaford 2003; see also Semenova 2011a, 2011b). It was in the vicinity of the chieftain's house that offerings to deities and communal sacrificial rituals were conducted. It was out of the chieftain's dwelling place that archaic Greek temples came to emerge, the temples being "among the very first manifestations of the polis" (Seaford 2003, 197). ${ }^{11}$ Similar to the case of ancient Egypt (see Henry 2004), ancient Greek religion served as a unifying social force, as the substance of socioeconomic relations was undergoing a fundamental transformation from egalitarian to hierarchical societies. While Homeric societies did not yet exhibit the features of the state proper, the transition from egalitarian to unequal societies already took place. Homeric societies featured political leaders whose power rested on their wealth and ability (though a limited one) to act as redistributors of the social surplus, as well as their authority over lower-status chiefs (Seaford 2003; see also Peacock 2013).

While the new political institution of the Greek polis was instrumental in the establishment of coinage, it would be misleading to assert that coinage emerged as a creature of a fully consolidated city-state (Peacock 2006, 645). Such an assertion "would imply that an already existing body, the state, created a new phenomenon, money" (645). Both coinage and poleis were the products of a long evolution, and as the developing city-state played a role in the emergence of coinage, so did coinage play a part in the rise of the city-state (see Peacock 2006, $644-645 ; 2013)$. It was not until the last quarter of the sixth century BC that we see some of the salient attributes of a state apparatus. And it is no coincidence that the final standardization of coinage did not occur until that time period, as well (von Reden 2003).

To conclude, while the state proper was not necessary for the introduction of money, the origins of money required the rise of a ruling class, as well as a corresponding transformation from egalitarian to socially-stratified societies. 


\section{THE RISE OF MONEY AND CLASS SOCIETY IN ANCIENT EGYPT: THE CONTRIBUTIONS OF JOHN HENRY}

Henry (2004) puts chartalist theories to a historical test when he applies them to the context of ancient Egypt. Henry's account of money's origins in ancient Egypt reveals trends remarkably similar to those observed in ancient Greece, namely that the origins of money were closely intertwined with a) the development of social stratification; b) the religious character of early non-egalitarian societies; and c) a fundamental shift in the substance of social obligations which corresponds to the shift from totemism to state religion.

According to Henry, up to about 4400, BC Egyptian populations lived in egalitarian, tribal arrangements. The first instances of inequality can be located in $4400-4000 \mathrm{BC}$, as indicated by the archeological evidence of grave burials. Within the next millennium (40003000 BC), inequality became more pronounced, carrying markedly into the Naqada III period (3500-3200 BC). At this time, we see some evidence of kingship emerging, though the new leaders would be properly described as proto-kings. Kings proper appeared after $3000 \mathrm{BC}$, along with a system of proto-taxation and a bureaucratic apparatus of the king. Importantly, at this time, one sees the rise of monumental temples and the development of state religion centered around the king. During the Early Dynastic Period (3000-2625 BC), inequality continued to grow and cemented itself as increasingly "normal," a development which culminated in the 2625-2130 BC period (the Old Kingdom), which saw a solidification of the relationship between the king (pharaoh) and the principal deity of the state religion (Henry 2004). Evidently, the rise of inequality was a gradual process which took place over thousands of years. Rather than taken for granted, the transition from egalitarian to unequal socioeconomic structures has to be explained. How exactly did this happen?

Henry explains that early successes in agriculture allowed for the creation of a small economic surplus which made it possible to release some labor from direct agricultural production. Yet, Henry cautions that the development of agriculture and surplus production in and of themselves cannot explain the rise of inequality. After all, the members of the tribal community could equally distribute the surplus amongst themselves. And "it was a thousand years from the dawn of agriculture to the first evidence of inequality" (Henry 2004, 84). 
Recognizing the importance of the division of labor, tribal societies would at some point designate a portion of the population to specialize solely in hydraulic activities to improve their ability to control the Nile (Henry 2004). At that time, a fixed share of surplus production would be designated for hydraulic activities and projects. As surplus production grew over time, with the share devoted to hydraulic activities remaining unchanged (as it was fixed by convention), the absolute amount of goods flowing to hydraulic engineers from the tribal villages grew. As this development took place gradually (due to the gradual increase in the surplus production), the absolute increases in tribal contributions to hydraulic projects were invisible at first. Contributing to this was also the physical separation of the engineers from the rest of the community.

As hydraulic engineers began to accumulate goods beyond that which was necessary for the carrying out of the hydraulic projects, the substance of social relations between the engineers and the tribal communities started to change. While the appearance of social relations may not have changed (after all, as customary, a fixed share of surplus production was flowing to the engineers), the substance of those relations was undergoing a fundamental transformation. Henry explains that with the growth of the surplus, all members of the community saw a rise in their standards of living. However, the hydraulic engineers saw a relatively greater increase, given that a fixed share of a growing surplus was being channeled to a relatively small group of the population. Henry estimates that in the early stages of this transformation the differences in growth rates were as little as .05 percent. However, over a thousand years, even a .05 -percent difference would lead to "clearly observable absolute differences" (Henry 2004, 85).

By the time inequality came to be strikingly visible, the now-dominant class (the former hydraulic engineers), needed to justify the new socioeconomic relations, as well as keep the flow of surplus production moving in their direction. To achieve that, the dominant class had to "present the veneer that nothing fundamental had changed when, in fact, everything of substance had been altered" (Henry 2004, 87, original emphasis). And it was through the apparatus of religion that the new ruling class presented an appearance of old communal relations, thus maintaining its grip on socioeconomic power (87).

Specifically, hydraulic engineers now turned priests, subverted the substance of tribal totemism by elevating the priest-king to a position of authority in communicating with nature (Henry 2004). In substance, this amounted to the rise of state religion, while communal obligations to support hydraulic projects were converted into "taxes" aimed at maintaining a 
privileged segment of the population. Furthermore, a bookkeeping system had to be developed through which tax assessments and payments could be recorded. And it was within this administrative bookkeeping context that a standardized unit of account — the deben unit—was introduced.

The deben unit was initially equated to 92 (or 91) grams of wheat. Later in the Old Kingdom, wheat was replaced by copper, and later yet, gold and silver superseded copper. Regardless of the particular good, the unit of account corresponded to a weight unit of 92 grams. While goods and labor services were valued in deben, no deben units could obviously change hands. Thus money came into being "as simply a non-tangible unit in which obligations are created and discharged" (Henry 2004, 93).

Henry's account of money's origins in ancient Egypt supports the chartalist view that money is not a "thing" but a social relation whereby a large group of the population is obligated to a minority group in a non-reciprocal fashion. In the words of Henry (2004):

It is not "the thing" that matters, but the ability of one section of the population to impose its standard on the majority, and the institutions through which that majority accepts the will of the minority. Money, then, as a unit of account, represents the class relations that developed in Egypt (and elsewhere), and class relations are social relations (95-96).

And, as noted earlier, state religion (disguised as the old tribal totemism) served as the primary institution through which the majority accepted the will of the minority.

Lastly, Henry's exposition makes it obvious that the rise of inequality in ancient Egypt was an accident of history, rather than history's natural progression. When tribal villages allocated a fixed portion of surplus production toward the maintenance of the Nile, they could not possibly foresee that over a thousand years this would lead to an emergence of a privileged socioeconomic class. The mere notion (or idea) of inequality could not possibly exist in an egalitarian society. Rather, the idea of inequality had to come from the practice of inequality, the latter being an unforeseen long-term consequence of a seemingly innocent tribal decision to support hydraulic engineers in their efforts to control the Nile (Henry 2004):

A segment of an egalitarian society cannot (and would not) simply set itself up as a separate and unequal class de novo. Where would this segment get its idea of inequality? The idea must follow from the practice of inequality, and this practice would have to develop as a consequence of historical accident rather than conscious plan. In Egypt, the 
process took over one thousand years to reach fruition and was initially the result of tribal decisions, the long-run consequences of which could not be foreseen (86-87).

\section{CONCLUSIONS: FROM CHARTALISM TO MODERN MONEY THEORY AND GREATER EQUALITY}

In this chapter, we examined the building blocks and the intellectual history of chartalism-an alternative approach to money and credit—now called Modern Money Theory (MMT). By examining the nature and origins of money in ancient Greece and ancient Egypt, we further demonstrated the historical applicability of the chartalist perspective. We will conclude by addressing the implications of the chartalist approach for our understanding of fiscal policy as practiced in the policy space available to a government that issues its own currency.

Firstly, modern money is a state money: the state chooses the money of account, imposes taxes and other obligations in that unit, and accepts payment in that unit. When it comes to the state's ability to issue IOUs (whether currency, central bank reserves, or Treasury securities), what matters is their acceptability on the demand side. As a sovereign power, however, the state can mandate at least some demand for its IOUs by imposing taxes that must be paid in the state's currency. Beyond that, by sitting at the apex of the "money pyramid," (see Bell 2001) the state's IOUs are demanded for clearing purposes and the maintenance of reserves (Wray 2014a).

Secondly, the chartalist framework conflicts with the conventional "government budget constraint" (GBC) notion, according to which government spending must be "financed" by tax revenues, borrowing, or "printing money." The GBC view essentially presumes that the government is a user of a currency, not an issuer. In that, the government is like a household or a firm, as it must obtain "income" (revenue from taxes, fees, and fines) or "borrow" (issue Treasury securities) (Wray 2014a).

Within the MMT framework, government spending logically comes first, i.e., before government obtains tax revenue or sells bonds. If the government receives in tax payments its own IOUs, it must first supply them before taxes can be paid. And if bond purchasers must use the government's IOUs to pay for the bonds, then the government must have spent (or lent) its IOUs before it sold the bonds. While it might appear that the bond sales "finance" Treasury spending, in reality, bond sales are undertaken to drain excess reserves that would push overnight interest rates below their policy target. In reality, money creation, tax receipts, and 
bond sales are all different parts of the process of government spending. They are not the alternative ways to "finance" government spending. This would have been more transparent if the sovereign governments spent by raising a tally or by minting new coin (Wray 2014b, 2014c).

Obviously, the state can impose constraints on its ability to issue IOUs, such as the budgetary process, a debt ceiling, a balanced budget requirement, or Maastricht-like debt and deficit limits. The state could make a sovereign currency system operate more like the imaginary commodity money system by requiring conversion on demand to gold or foreign currency. Any of the above constraints would necessarily be self-imposed political constraints, as they do not come about "naturally" due to a "commodity nature" of money (Wray 2014a).

The government's ability to impose liabilities, name the unit of account, and issue the money used to pay down these liabilities gives a substantial measure of power to the authority (see Wray 2014d; see also Wray 2000). ${ }^{12}$ There is, thus, the potential to use this power to further the public good through the use of fiscal, social and employment policies, as was the case during the "Age of Keynes" (1947-1975). During that time, the US government "enforced the basic bargain — using Keynesian policy to achieve nearly full employment, giving ordinary workers more bargaining power, providing social insurance, and expanding public investment. Consequently, the share of total income that went to the middle class grew while the portion going to the top declined" (Reich 2013, 49). During the Keynesian period, "Almost everyone who wanted a job could find one with good wages, or at least [real] wages that were trending upward" (43). Everyone saw their real income grow, not just the top 1 percent or the top 10 percent of income earners (43).

As is well known, Keynesian policies came to an end by the mid 1970s. Ever since then, the trend toward greater equality has been reversed. Since 1976, the bottom 20 percent of income earners saw their real incomes stagnate as more and more wealth and income accrued to the very top. In 2007, 23 percent of all income in the US accrued to the top 1 percent of income earners (compared to 8 percent of all income in 1980) (Reich 2010). Confronted with stagnant real wages, American workers increasingly had to rely on debt to support their standards of living, thereby supporting the interest and other income of the financial sector.

While in the late 1970s fiscal policy was downgraded due to its alleged inflationary impact (see Taylor 2011), today's discourse on fiscal policy is centered around a false belief that government's spending is financially constrained by the government's ability to tax or borrow. 
chartalism and MMT make it clear that any constraints on government's spending are selfimposed institutional constraints which could be removed via a democratic decision-making process.

While the origins of money are to be found in the origins of inequality, a wellfunctioning democratic society has the power to subvert the inequality-inducing characteristic of money via the use of money for public purpose. Examples include federal funding for locally administered jobs, as well as the federal government's support for a living wage. There are numerous areas where federally funded jobs could be created and maintained: public infrastructure (including green energy projects), education, community development, public health care, public housing, and social services, among others. Such programs would support a stronger middle class thereby reducing the power of the financial sector, as reliance on credit would be significantly lowered. The federal government could likewise support a universal, single-payer health care system, thereby eliminating for-profit health insurance companies who have enjoyed skyrocketing profits while medical debt among households with health insurance has been rising. In 2007, medical bills contributed to 62 percent of personal bankruptcies in the US, while three quarters of those who filed for bankruptcy due to medical bills had health insurance on the onset of illness (The Henry J. Kaiser Family Foundation 2014).

Income and wealth inequality is not simply a matter of economic injustice. The costs of inequality encompass deteriorating mental and physical health, including the obesity epidemic; poor educational performance among children; and erosion of community life and social relations, among others (see Wilkinson and Pickett 2010). MMT unveils the power of the monetary system to serve the public interest by restoring healthy and functional communities and building a more equitable and just future via government's commitment to full employment. There are no "financial constraints" that prevent the government from achieving these goals.

The real problem is not the financial "imbalances," such as the government's budget deficits, but rather the imbalance of power brought about by the false belief that the government is financially constrained in its ability to fight unemployment, inequality, and poverty, as well as provide adequate healthcare, retirement, and welfare benefits. As a result of this false ideology, too much power has concentrated in the hand of the financial sector; too many of the former public assets have been privatized in pursuit of the private gain; and too-little use of the democratic government has remained to serve the public interest. The "predator state" 
(Galbraith 2009) has to be replaced with a government of the people operating for the public purpose via the use of modern money (Wray 2012b). 


\section{References}

Atwood, M. 2008. Payback: Debt and the Shadow Side of Wealth. Toronto: House of Anansi Press Inc.

Bell, S. 2001. "The Role of the State and the Hierarchy of Money." Cambridge Journal of Economics, 25 (2): 149-163

Bell, S. and J.F. Henry. 2001. "Hospitality versus Exchange: The Limits of Monetary Economies." Review of Social Economy, 59 (2): 203-226.

Bell, S., J.F. Henry, and L.R. Wray. 2004. "A Chartalist Critique of John Locke's Theory of Property, Accumulation, and Money: Or Is It Moral to Trade Your Nuts for Gold?" Review of Social Economy, 62 (1): 51-65.

Cook, R.M. 1958. "Speculation on the Origins of Coinage." Historia 7: 257-262.

Desmonde, W.H. 1962. Magic, Myth, and Money: The Origin of Money in Religious Ritual. New York: The Free Press of Glencoe, Inc.

Finley, M.I. [1953] 1981. Economy and Society in Ancient Greece. New York: Penguin Books Ltd.

Galbraith, J.K. 2009. The Predator State: How Conservatives Abandoned the Free Market and Why Liberals Should Too. New York, NY: Free Press.

Gardner, P. 1883. The Types of Greek Coins. Cambridge: Cambridge University Press.

Goodhart, C.A.E. [1975] 1989. Money, Information and Uncertainty. Cambridge, MA: The MIT Press.

1998. "The Two Concepts of Money: Implications for the Analysis of Optimal

Currency Areas.” European Journal of Political Economy, 14 (3): 407-432.

Grierson, P. 1975. Numismatics. London: Oxford University Press.

1977. The Origins of Money. London: The Athlone Press, University of London.

Head, B. V. [1894] 1968. "Greek Coins." In Coins and Medals: Their Place in History and Art, edited by S. Lane-Poole, pp. 10-41. Chicago: Argonaut, Inc., Publishers.

Henry, J. F. 1990. The Making of Neo-Classical Economics. London: Unwin Hyman.

2004. "The Social Origins of Money: The Case of Egypt." In Credit and State Theories of Money: The Contributions of A. Mitchell Innes, edited by L. R. Wray, pp. 70-98. Cheltenham and Northampton: Edward Elgar.

The Henry J. Kaiser Family Foundation. 2014. "Medical Debt among People with Health Insurance.” Report. Accessed September 15, 2014. 
http://kaiserfamilyfoundation.files.wordpress.com/2014/01/8537-medical-debt-among- with-health-insurance.pdf

Howgego, C. 1995. Ancient History from Coins. London and New York: Routledge.

Hudson, M. 2004. "The Archeology of Money: Debt versus Barter Theories of Money's Origins." In Credit and State Theories of Money: The Contributions of A. Mitchell Innes, edited by L. R. Wray, pp. 99-127. Cheltenham and Northampton: Edward Elgar.

Innes, A.M. 1913. "What Is Money?” The Banking Law Journal, (30): 377-408.

1914. "The Credit Theory of Money." The Banking Law Journal, (31): 151-168.

1932. Martyrdom in Our Times: Two Essays on Prisons and Punishments. London:

Williams and Norgate Ltd.

Ingham, G. 1996. “Money is a Social Relation.” Review of Social Economy, 54 (4): 507-529.

2000. "'Babylonian Madness': On the Historical and Sociological Origins of Money." In What Is Money?, edited by J. Smithin, pp. 16-41. London and New York: Routledge.

2004a. The Nature of Money. Cambridge and Malden: Polity Press.

2004b. "The Nature of Money." Economic Sociology: European electronic newsletter, 5

(2): 18-28.

2013. "Oh Sacred Hunger of Pernicious Gold! What Bands of Faith Can Impious Lucre Hold?" European Journal of Sociology, 54 (1): 127-146.

Keynes, J.M. 1930. A Treatise on Money. Volumes I and II, New York: Harcourt, Brace \& Company.

Knapp, G.F. [1905] 1924. The State Theory of Money, translated by H.M. Lucas and J. Bonar. London: Macmillan and Co., Ltd.

Kraay, C.M. 1964. "Hoards, Small Change and the Origin of Coinage." The Journal of Hellenistic Studies, 84: 76-91. 1976. Archaic and Classical Greek Coins. New York: Sanford J. Durst.

Kurke, L. 1999. Coins, Bodies, Games and Gold: The Politics of Meaning in Archaic Greece. Princeton: Princeton University Press.

Laum, B. 1924. Heiliges Geld: Eine Historishe Untersuchung über den Sakralen Ursprung des Geldes. Tübingen: Verlag von J. C. B. Mohr.

Lerner, A.P. 1947. "Money as a Creature of the State." The American Economic Review, 37 (2): 312-317. 
Mann, M. 1993. The Rise of Classes and Nation-States, 1760 - 1914. Vol. 2 of The Sources of Social Power. Cambridge: Cambridge University Press.

Martin, T.R. 1996. "Why Did the Greek "Polis" Originally Need Coins?" Historia: Zeitschrift für Alte Geschichte, 45 (3): 257-283. [1996] 2000. Ancient Greece: From Prehistoric to Hellenistic Times. New Haven and London: Yale University Press.

Menger, C. [1871] 1981. Principles of Economics, translated by J. Dingwall, and B. F. Hoselitz. New York and London: New York University Press.

"On the Origins of Money." The Economic Journal, 2 (5): 239-255.

1900. “Geld.” In Handwörterbuch der Staatswissenschaften 4, edited by J. Conrad, L. Elster, W. Lexis, and E. Loening. Jena: G. Fischer.

[1909] 2002. "Money." In Carl Menger and the Evolution of Payments Systems: From Barter to Electronic Money, edited by M. Latzer and S. W. Schmitz, pp. 25-107. Cheltenham and Northampton: Edward Elgar.

Migeotte, L. [2002] 2009. The Economy of the Greek Cities: From the Archaic Period to the Early Roman Empire, translated by J. Lloyd. Berkeley: University of California Press.

Minar, E.L. 1942. Early Pythagorean Politics in Practice and Theory. Baltimore: Waverly Press.

Morgan, L.H. [1877] 1985. Ancient Society. Tucson: University of Arizona Press.

Peacock, M.S. 2006. "The Origins of Money in Ancient Greece: The Political Economy of Coinage and Exchange.” Review Article. Cambridge Journal of Economics, 30 (4): 637650 .

2011. "The Political Economy of Homeric Society and the Origins of Money." Contributions to Political Economy, 30 (1): 47-65.

2013. Introducing Money. London and New York: Routledge.

Piketty, T. 2014. Capital in the Twenty-First Century. Cambridge and London: The Belknap Press of Harvard University Press.

Reich, R. 2010. "Foreword.” In The Spirit Level: Why Greater Equality Makes Societies Stronger, by R. Wilkinson and K. Pickett, pp. ix-xii. New York: Bloomsbury Press. [2011] 2013. Aftershock: The Next Economy and America's Future. New York: Vintage Books.

Seaford, R. [1994] 2003. Reciprocity and Ritual: Homer and Tragedy in the Developing CityState. Oxford: Oxford University Press. 
2004. Money and the Early Greek Mind: Homer, Philosophy, Tragedy. Cambridge: Cambridge University Press.

Semenova, A. 2011a. "Would You Barter with God? Why Holy Debts and Not Profane Markets Created Money." American Journal of Economics and Sociology, 70 (2): 376-400.

2011b. The Origins of Money: Evaluating Chartalist and Metallist Theories in the Context of Ancient Greece and Mesopotamia. PhD Thesis. University of MissouriKansas City.

2014. "Carl Menger's Theory of Money's Origins: Responding to Revisionism.” The European Journal of the History of Economic Thought, 21 (1): 107-141.

Spengler, J.J. 1980. Origins of Economic Thought and Justice. London and Amsterdam: Feffer \& Simons, Inc.

Stiglitz, J.E. 2013. The Price of Inequality: How Today's Divided Society Endangers Our Future. New York: W.W. Norton and Company.

Taibbi, M. 2014. The Divide: American Injustice in the Age of the Wealth Gap. Spiegel and Grau.

Taylor, C. 2011. A Macroeconomic Regime for the $21^{\text {st }}$ Century: Towards a New Economic Order. London and New York: Routledge.

van der Vliet, E. C. L. 1998. Review of Exchange in Ancient Greece, by Sitta von Reden. Mnemosyne, 51 (4): 497-500.

von Braun, C. 2006. "Einleitung." In Heiliges Geld: Eine Historische Untersuchung über den Sakralen Ursprung des Geldes. Berlin: Semele Verlag.

von Reden, S. [1995] 2003. Exchange in Ancient Greece. Gerald Duckworth \& Co. Ltd. London.

2001. "The Politics of Monetization in Third-Century BC Egypt." In Money and Its Uses in the Ancient Greek World, edited by A. Meadows and K. Shipton, pp. 65-76. Oxford: Oxford University Press.

Wilkinson. R., and K. Pickett. 2009. The Spirit Level: Why Greater Equality Makes Societies Stronger. New York and London: Bloomsbury Press.

Wray, L.R. 1998. Understanding Modern Money: The Key to Full Employment and Price Stability. Cheltenham and Northampton: Edward Elgar.

2000. "Modern Money." In What Is Money?, edited by J. Smithin, pp. 42-66. London and New York: Routledge. 
2004. "Conclusion: The Credit Money and State Money Approaches." In Credit and State Theories of Money: The Contributions of A. Mitchell Innes, edited by L. R. Wray, pp. 223-262. Cheltenham and Northampton: Edward Elgar.

2012a. Modern Money Theory: A Primer on Macroeconomics for Sovereign Monetary Systems. Palgrave Macmillan.

2012b. "Imbalances? What Imbalances? A Dissenting View." Levy Economics Institute Working Paper No. 704. Accessed September 6, 2014.

http://www.levyinstitute.org/pubs/wp_704.pdf

2012c. "Introduction to an Alternative History of Money." Levy Economics Institute Working Paper 717. Accessed September 6, 2014. http://www.levyinstitute.org/pubs/wp_717.pdf

2014a. "From the State Theory of Money to Modern Money Theory: An Alternative to Economic Orthodoxy." Levy Economics Institute Working Paper No. 792. Accessed September 6, 2014. http://www.levyinstitute.org/publications/from-the-state-theory-ofmoney-to-modern-money-theory

2014b. "Central Bank Independence: Myth and Misunderstandin.” Levy Economics Institute Working Paper No. 791. Accessed September 6, 2014.

http://www.levyinstitute.org/publications/central-bank-independence

2014c. "Outside Money: The Advantages of Owning the Magic Porridge Pot." Working Paper.

2014d. "The Reality of the Present and the Challenge of the Future: Fagg Foster for the $21^{\text {st }}$ Century." Journal of Economic Issues, forthcoming.

Wray, L.R. and S. Bell. 2004. "Introduction." In Credit and State Theories of Money: The Contributions of A. Mitchell Innes, edited by L. R. Wray, pp. 1-13. Cheltenham and Northampton: Edward Elgar. 


\section{Endnotes}

${ }^{1}$ For a detailed exposition of the metallist approach, see Menger 1871, 1892, 1900, 1909. For a detailed exposition and a critique of metallism, see Wray 1998; Semenova 2011a, 2011 b, 2014.

${ }^{2}$ The terms chartal and chartalism derive from Greek chórtēs meaning papyrus leaf, sheet of paper, literally something to make marks on.

${ }^{3}$ While social obligations existed in egalitarian societies, "such obligations were internal to the collective itself and of a reciprocal nature: all had obligations to all" (Henry 2004, 84). Social arrangements where some owed obligations to others in a non-reciprocal manner did not exist in egalitarian societies (84).

${ }^{4}$ Recently, Laum's (1924) contribution has been revived by Seaford (2004), von Braun (2006), Peacock (2011, 2013) and Semenova (2011a, 2011b).

${ }^{5}$ While Homer provides detailed descriptions of the rituals, the sourcing of sacrificial animals receives little attention (Seaford 2004). Most likely, though, sacrificial offerings were made by the nobles who were among the few who actually owned cattle and other highly prestigious goods (Peacock 2013; see also Martin 1996).

${ }^{6}$ Martin (2000) observes the existence of social hierarchies in Greek societies as early as 950 BC.

${ }^{7}$ An example of just compensation could be misthos received by the Athenian citizens for the services rendered to the polis. Unlike wage, which is payment for hired labor, misthos represented a "collective counter-gift" from the polis to the citizen to compensate and express his timè (worth) (van der Vliet 1998, 499).

${ }^{9}$ The association between citizens and coinage can be confirmed by the Athenian legal practice of dokimasia. Derived from dokimos, meaning to examine and approve coinage, dokimasia was a fourth century BC procedure via which the polis "proofed its citizens, testing the quality of their birth and behavior" (Kurke 1999, 310).

${ }^{10}$ As is well established, women were regarded as minors, as dependents of men, be it a husband, a father, a son, or a male relative (Migeotte 2009; Atwood 2008).

${ }^{11}$ A similar observation was made by Morgan ([1877] 1985) who traced the transition from "democratic gens" $(1985,67)$ to hierarchical social arrangements led by the office of a "high priest." Morgan concluded that "the gens became the natural centre of religious growth and the birthplace of religious ceremonies" (Ibid., 81).

${ }^{12}$ It bears noting Michael Mann's distinction between "despotic" and "infrastructural" power of the state (see Mann 1993, 59-64). Ingham (2004b) applied this distinction to the institution of money, thus underscoring money's "dual nature" (20). While money can expand a given "society's capacity to get things done, as Keynesian economics emphasizes," this infrastructural power of money "can be appropriated by particular interests" (20). 